\title{
REVITALISASI KEBIJAKAN NASIONAL PEMBANGUNAN KARAKTER BANGSA MELALUI PENDIDIKAN KARAKTER DI SEKOLAH
}

\author{
Praptining Sukowati \\ Fakultas Ilmu Sosial \& Ilmu Politik Universitas Merdeka Malang \\ e-mail : praptining@unmer.ac.id
}

\begin{abstract}
ABSTRAK
Haruslah diyakini bahwa tidak perlu ada keraguan dari seluruh komponen bangsa tentang perlunya pembangunan bangsa dan karakter yang oleh Ir Soekarno Presiden RI Pertama ditemakan dengan nation and character building karena secara konstitusional komitmen berbangsa dan bernegara Indonesia telah dengan tegas dinyatakan dalam keempat alinea Pembukaan UUD 1945. Komitmen tersebut merupakan kristalisasi dari semangat kebangsaan yang secara historis mengkristal dalam wujud gerakan Kebangkitan Nasional 1908, Sumpah Pemuda 28 Oktober 1928, yang berpuncak dengan Proklamasi Kemerdekaan Indonesia 17 Agustus 1945. Karena itu kegalauan seluruh komponen bangsa tentang kondisi bangsa yang dirasakan menghawatirkan saat ini, dan prospek bangsa dan negara Indonesia di masa depan. Di era Presiden Joko Widodo sekarang kembali dikuatkan melalui program pembangunan karakter bangsa yang bertema "Revolusi Mental", yang tema besarnya prinsipnya sama untuk membangun karakter merupakan indikator yang kuat bahwa seluruh komponen bangsa memiliki komitmen kebangsaan yang sangat kuat sehingga perlu didukung dengan adanya kebijakan nasional yang komprehensif, koheren, dan berkelanjutan.
\end{abstract}

Kata kunci : Revitalisasi, kebijakan, pembangunan, pendidikan karakter

\section{PENDAHULUAN}

Lima pilar pemberdayaan keluarga adalah 1) Pendidikan, 2) kesehatan, 3) Lingkungan, 4) Ekonomi dan 5) Agama dan Budaya. Sebagai mitra binaan LPPM, Posdaya telah melakukan pemberdayaan kepada masyarakat sekitar dengan ikut aktif dalam mengelola PAUD Pemberdayaan secara substansial merupakan proses memutus atau break down hubungan antara subyek dan obyek. Proses ini mementingkan pengakuan subyek akan kemampuan atau daya (power) yang dimiliki obyek. Pemberdayaan masyarakat menjadi suatu agenda penting yang harus dilakukan secara menyeluruh.Namun hingga saat ini pada tingkat regional, kegiatan pemberdayaan belum mencapai sasaran dan menghasilkan out put yang diharapkan, karena tingkat kemiskinan masih relatif tinggi.

Salah satu program pemberdayaan masyarakat yang dilakukan Universitas Merdeka Malang adalah program POSDAYA (Pos Pemberdayaan Keluarga). Posdaya merupakan forum silaturahmi, komunikasi, dan wadah kegiatan penguatan fungsi keluarga secara terpadu. Yang kegiatannya menitikberatkan pada 5 pilar pemberdayaan yakni bidang ekonomi produktif, bidang pendidikan, bidang kesehatan, bidang lingkungan dan bidang sosial budaya.Penguatan pilar-pilar utama tersebut diharapkan dapat memberi penguatan bagi keluarga untuk menjadi keluarga mandiri dan sejahtera sehingga mampu menghadapi tantangan kehidupan. Yang pada intinya dengan pemberdayaan ini masyarakat bisa memenuhi kebutuhan ekonomi, kesehatan prima, pendidikan layak, lingkungan sehat, dan memiliki kehidupan beragama serta berkehidupan sosial yang semakin membaik. Pemberdayaan masyarakat yang dilakukan oleh tim dengan menggandeng Posdaya yang ada diwilayah Malang Raya.

\section{Pentingnya Pendidikan Anak Usia Dini}

Yang dimaksud dengan anak usia dini adalah anak dalam rentangan 0-6 tahun menurut Pasal $28 \mathrm{UU}$ Sisdiknas No.20/2013 ayat 1. Sementara menurut kajian rumpun keilmuan PAUD dan penyelenggaraannya di beberapa negara, PAUD dilaksanakan sejak usia 0-8 tahun (masa emas). Pendidikan anak usia dini (PAUD) adalah jenjang pendidikan sebelum jenjang pendidikan dasar yang merupakan suatu upaya pembinaan yang ditujukan bagi anak sejak lahir sampai dengan usia enam tahun yang dilakukan melalui pemberian rangsangan pendidikan untuk membantu pertumbuhan dan perkembangan jasmani dan rohani agar anak memiliki kesiapan dalam memasuki pendidikan lebih lanjut, yang diselenggarakan pada jalur formal, nonformal, dan informal. Sementara ruang Lingkup Pendidikan Anak Usia Dini :

- Infant (0-1 tahun)

- Toddler (2-3 tahun) 
- Preschool/ Kindergarten children (3-6 tahun)

- Early Primary School (SD Kelas Awal) (6-8 tahun)

Pendidikan anak usia dini merupakan salah satu bentuk penyelenggaraan pendidikan yang menitikberatkan pada peletakan dasar ke arah pertumbuhan dan 5 perkembangan, yaitu : perkembangan moral dan agama, perkembangan fisik (koordinasi motorik halus dan kasar), kecerdasan/kognitif (daya pikir, daya cipta), sosio emosional (sikap dan emosi) bahasa dan komunikasi, sesuai dengan keunikan dan tahap-tahap perkembangan sesuai kelompok usia yang dilalui oleh anak usia dini seperti yang tercantum dalam Permendiknas no 58 tahun 2009.

Ada dua tujuan diselenggarakannya pendidikan anak usia dini yaitu:

- Tujuan utama: untuk membentuk anak Indonesia yang berkualitas, yaitu anak yang tumbuh dan berkembang sesuai dengan tingkat perkembangannya sehingga memiliki kesiapan yang optimal di dalam memasuki pendidikan dasar serta mengarungi kehidupan pada masa dewasa.

- Tujuan penyerta: untuk membantu menyiapkan anak mencapai kesiapan belajar (akademik) di sekolah, sehingga dapat mengurangi usia putus sekolah dan mampu bersaing secara sehat di jenjang pendidikan berikutnya.

\section{METODE KEGIATAN}

Kegiatan Revitalisasi Kebijakan Nasional Pembangunan Karakter Bangsa Melalui Pendidikan Karakter Di Sekolah dilaksanakan oleh Lembaga Pelatihan Kerja Universitas Medeka Malang bekerjasama dengan Dinas Pendidikan Provinsi Jawa Timur yang melibatkan siswa sekolah, guru dan pengawas sekolah. Kegiatan dilakukan melalui beberapa tahap meliputi :

\section{Kegiatan Sosialisasi Program}

Kegiatan Sosialisasi Program dilakukan dalam rangka menyampaikan visi, misi dan tujuan dari kegiatan "Revitalisasi Kebijakan Nasional Pembangunan Karakter Bangsa Melalui Pendidikan Karakter Di Sekolah" tersebut kepada Kepala Sekolah, di wilayah Provinsi Jawa Timur. Adapun materi sosialisasi pada prinsipnya disampaikan sebagai berikut:

Situasi dan kondisi kondisi karakter bangsa yang yang saat ini cenderung memprihatinkan, yang mendorong pemerintah untuk mengambil memprioritaskan pembangunan karakter bangsa.
Pembangunan karakter bangsa dijadikan arus utama pembangunan nasional. Hal itu mengandung arti bahwa setiap upaya pembangunan harus selalu diarahkan untuk memberi dampak positif terhadap pengembangan karaker. Mengenai hal tersebut secara konstitusional sesungguhn ya sudah tecermin dari misi pembangunan nasional yang memosisikan pendidikan karakter sebagai misi pertama dari delapan misi guna mewujudkan visi pembangunan nasional, sebagaimana tercantum dalam Rencana Pembangunan Jangka Panjang Nasional Tahun 2005-2025 (Undang-Undang Republik Indonesia Nomor 17 Tahun 2007), yaitu “...terwujudnya karakter bangsa yang tangguh, kompetitif, berakhlak mulia, dan bermoral berdasarkan Pancasila, yang dicirikan dengan watak dan prilaku manusia dan masyarakat Indonesia yang beragam, beriman dan bertakwa kepada Tuhan Yang Maha Esa, berbudi luhur, bertoleran, bergotongroyong, berjiwa patriotik, berkembang dinamis, dan berorientasi ipteks."

Oleh karena itu pembangunan karakter bangsa memiliki cakupan dan tingkat urgensi yang sangat luas dan bersifat multidimensional. Ditegaskan dalam Kebijakan tersebut sangat luas karena memang secara substantif dan operasional terkait dengan “...pengembangan seluruh aspek potensi-potensi keunggulan bangsa dan bersifat multidimensional karena mencakup dimensi-dimensi kebangsaan yang hingga saat ini sedang dalam proses "menjadi". Dalam hal ini dapat juga disebutkan bahwa (1) karakter merupakan hal sangat esensial dalam berbangsa dan bernegara, hilangnya karakter akan menyebabkan hilangnya generasi penerus bangsa; (2) karakter berperan sebagai "kemudi" dan kekuatan sehingga bangsa ini tidak terombang-ambing; (3) karakter tidak datang dengan sendirinya, tetapi harus dibangun dan dibentuk untuk menjadi bangsa yang bermartabat. Selanjutnya, ditegaskan bahwa pembangunan karakter bangsa harus difokuskan pada "...tiga tataran besar, yaitu (1) untuk menumbuhkan dan memperkuat jati diri bangsa, (2) untuk menjaga keutuhan Negara Kesatuan Republik Indonesia (NKRI), dan (3) untuk membentuk manusia dan masyarakat Indonesia yang berakhlak mulia dan bangsa yang bermartabat."

Di dalam Kebijakan Nasional tersebut $(2010 ; 4)$ pembangunan karakter bangsa secara fungsional memiliki tiga fungsi utama sebagai berikut. a. Fungsi Pembentukan dan Pengembangan Potensi Pembangunan karakter bangsa berfungsi membentuk dan mengembangkan potensi manusia atau warga negara Indonesia agar berpikiran baik, berhati baik, dan berperilaku baik sesuai dengan falsafah hidup 
Pancasila. b. Fungsi Perbaikan dan Penguatan Pembangunan karakter bangsa berfungsi memperbaiki dan memperkuat peran keluarga, satuan pendidikan, masyarakat, dan pemerintah untuk ikut berpartisipasi dan bertanggung jawab dalam pengembangan potensi warga negara dan pembangunan bangsa menuju bangsa yang maju, mandiri, dan sejahtera. c. Fungsi Penyaring Pembangunan karakter bangsa berfungsi memilah budaya bangsa sendiri dan menyaring budaya bangsa lain yang tidak sesuai dengan nilai-nilai budaya dan karakter bangsa yang bermartabat. Demikian ditegaskan bahwa "...ketiga fungsi tersebut dilakukan melalui (1) Pengukuhan Pancasila sebagai falsafah dan ideologi negara, (2) Pengukuhan nilai dan norma konstitusional UUD 45, (3) Penguatan komitmen kebangsaan Negara Kesatuan Republik Indonesia (NKRI), (4) Penguatan nilai-nilai keberagaman sesuai dengan konsepsi Bhinneka Tunggal Ika, serta (5) Penguatan keunggulan dan daya saing bangsa untuk keberlanjutan kehidupan bermasyarakat, berbangsa, dan bernegara Indonesia dalam konteks global."

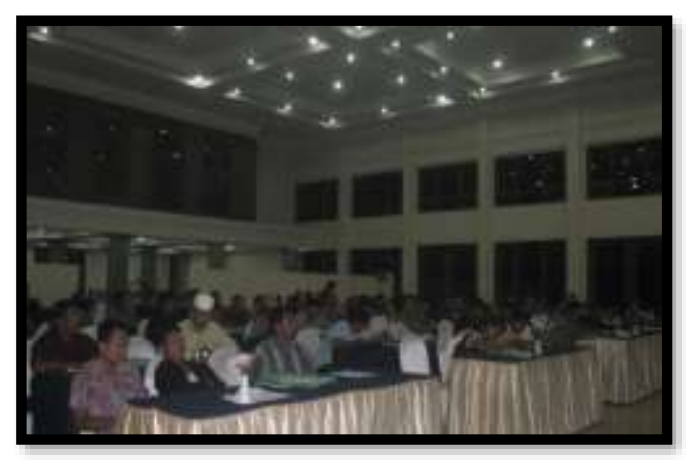

Gambar 1: Pelaksanaan Workshop dan peserta

\section{Workshop}

Setelah sosialisasi dilaksanakan workshop "Revitalisasi Kebijakan Nasional Pembangunan Karakter Bangsa Melalui Pendidikan Karakter Di Sekolah", dengan tujuan penguatan kembali karakter bangsa melalui beberapa program yang perlu dilakukan di tingkat sekolah-sekolah. Dimana yang menjadi tujuan (Kebijakan Nasional,2010:5) dari pembangunan karakter bangsa adaalah "...untuk membina dan mengembangkan karakter warga negara sehingga mampu mewujudkan masyarakat yang berKetuhanan Yang Maha Esa, berkemanusiaan yang adil dan beradab, berjiwa persatuan Indonesia, berjiwa kerakyatan yang dipimpin oleh hikmat kebijaksanaan dalam permusyawaratan perwakilan, serta berkeadilan sosial bagi seluruh rakyat Indonesia." Untuk itu maka Pembangunan Karakter Bangsa disikapi dan diperlakukan sebagai suatu gerakan nasional yang harus menjadi komitmen seluruh komponen bangsa dengan tema "...membangun generasi Indonesia yang jujur, cerdas, tangguh, dan peduli." Diantaranya seperti disampaikan dalam slade sebagai berikut:

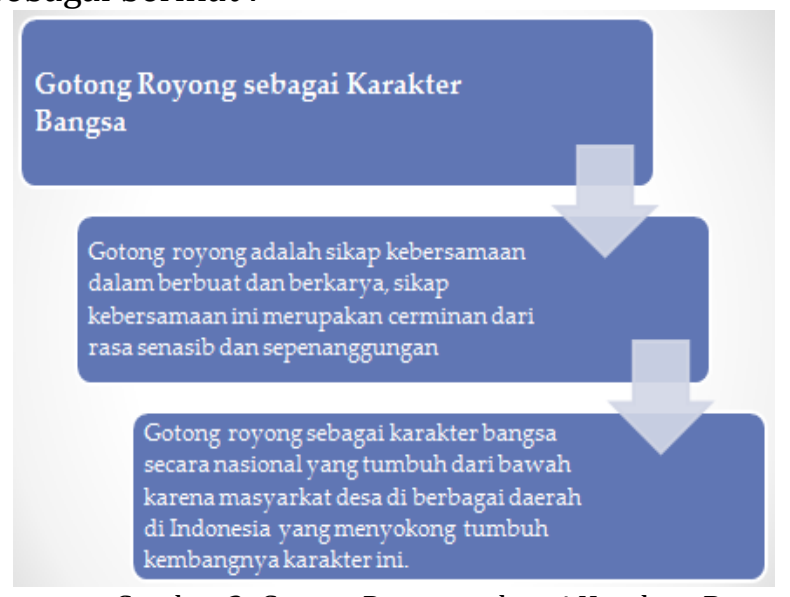

Gambar 2: Gotong Royong sebagai Karakter Bangsa

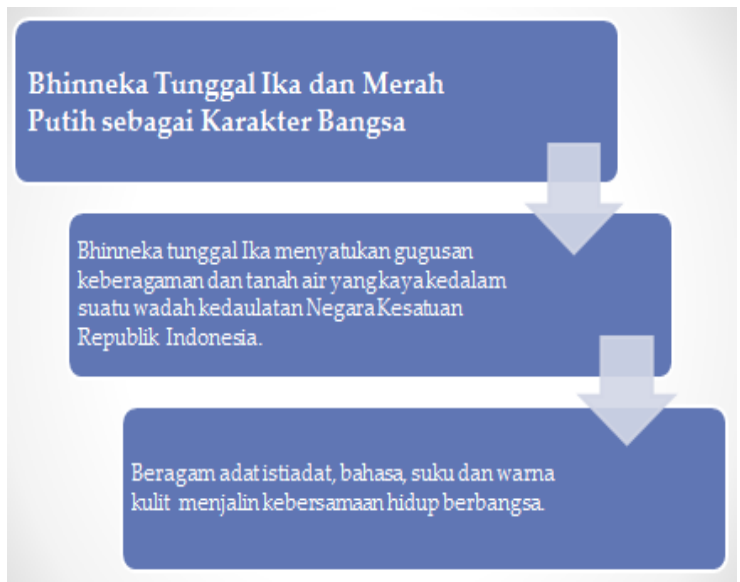

Gambar 3: Bhinneka Tunggal Ika dan Merah Putih sebagai Karakter Bangsa

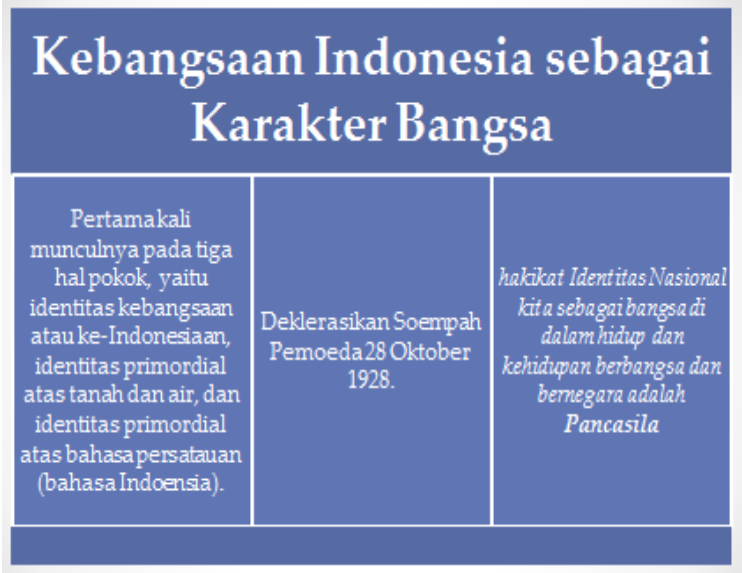

Gambar 4: Kebangsaan Indonesia sebagai Karakter Bangsa 


\section{Seminar}

Kegiatan terakhir dilakukan seminar dengan tema "Revitalisasi Kebijakan Nasional Pembangunan Karakter Bangsa Melalui Pendidikan Karakter Di Sekolah". Hasil dari seminar tersebut prinsipnya disampaikan bahwa melihat sifat komprehensif dan kompleksitas dari pembangunan karakter bangsa tersebut, telah ditetapkan yang menjadi lingkup sasaran pembangunan karakter bangsa mencakup ranah sebagai berikut.

1. Lingkup Keluarga yang “...merupakan wahana pembelajaran dan pembiasaan karakter yang dilakukan oleh orang tua dan orang dewasa lain dalam keluarga terhadap anak sebagai anggota keluarga sehingga diharapkan dapat terwujud keluarga berkarakter mulia yang tecermin dalam perilaku keseharian."

2. Lingkup Satuan Pendidikan yang “...merupakan wahana pembinaan dan pengembangan karakter yang dilakukan dengan menggunakan (a) pendekatan terintegrasi dalam semua mata pelajaran, (b) pengembangan budaya satuan pendidikan, (c) pelaksanaan kegiatan kokurikuler dan ekstrakurikuler, serta (d) pembiasaan perilaku dalam kehidupan di lingkungan satuan pendidikan. Pembangunan karakter melalui satuan pendidikan dilakukan mulai dari pendidikan usia dini sampai pendidikan tinggi."

3. Lingkup Pemerintahan yang “...merupakan wahana pembangunan karakter bangsa melalui keteladanan penyelenggara negara, elite pemerintah, dan elite politik. Unsur pemerintahan merupakan komponen yang sangat penting dalam proses pembentukan karakter bangsa karena aparatur negara sebagai penyelenggara pemerintahan merupakan pengambil dan pelaksana kebijakan yang ikut menentukan berhasilnya pembangunan karakter pada tataran informal, formal, dan nonformal." Pemerintahlah yang mengeluarkan berbagai kebijakan dalam

4. Lingkup Masyarakat Sipil yang “...merupakan wahana pembinaan dan pengembangan karakter melalui keteladanan tokoh dan pemimpin masyarakat serta berbagai kelompok masyarakat yang tergabung dalam organisasi sosial kemasyarakatan sehingga nilai-nilai karakter dapat diinternalisasi menjadi perilaku dan budaya dalam kehidupan sehari-hari”.

5. Lingkup Masyarakat Politik yang “...merupakan wahana yang melibatkan warga negara dalam penyaluran aspirasi dalam politik. Masyarakat politik merupakan suara representatif dari segenap elite politik dan simpatisannya. Masyarakat politik memiliki nilai strategis dalam pembangunan karakter bangsa karena semua partai politik memiliki dasar yang mengarah pada terwujudnya upaya demokratisasi yang bermartabat."

6. Lingkup Dunia Usaha dan Industri yang “...merupakan wahana interaksi para pelaku sektor riil yang menopang bidang perekonomian nasional. Kemandirian perekonomian nasional sangat bergantung pada kekuatan karakter para pelaku usaha dan industri yang di antaranya dicerminkan oleh menguatnya daya saing, meningkatnya lapangan kerja, dan kebanggaan terhadap produk bangsa sendiri."

7. Lingkup Media Massa yang “...merupakan sebuah fungsi dan sistem yang memberi pengaruh sangat signifikan terhadap publik, khususnya terkait dengan pembentukan nilai-nilai kehidupan, sikap, perilaku, dan kepribadian atau jati diri bangsa. Media massa, baik elektronik maupun cetak memiliki fungsi edukatif atau pun nonedukatif bergantung dari muatan pesan informasi yang disampaikannya."

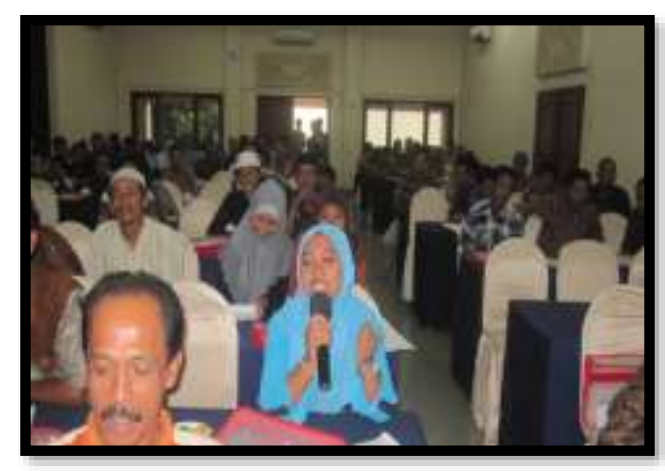

Gambar 5 : Kegiatan Seminar

\section{HASIL DAN PEMBAHASAN}

Di dalam Kebijakan Nasional, karakter diartikan sebagai “... nilai-nilai yang khas-baik (tahu nilai kebaikan, mau berbuat baik, nyata berkehidupan baik, dan berdampak baik terhadap lingkungan) yang terpateri dalam diri dan terejawantahkan dalam perilaku. Karakter secara koheren memancar dari hasil olah pikir, olah hati, olah raga, serta olah rasa dan karsa seseorang atau sekelompok orang. Karakter merupakan ciri khas seseorang atau sekelompok orang yang mengandung nilai, kemampuan, kapasitas moral, dan ketegaran dalam menghadapi kesulitan dan tantangan". Sedangkan karakter bangsa adalah kualitas perilaku kolektif kebangsaan yang khas-baik yang tecermin dalam kesadaran, pemahaman, rasa, karsa, dan perilaku berbangsa dan bernegara sebagai hasil olah pikir, 
olah hati, olah rasa dan karsa, serta olah raga seseorang atau sekelompok orang. Karakter bangsa Indonesia akan menentukan perilaku kolektif kebangsaan Indonesia yang khas-baik yang tecermin dalam kesadaran, pemahaman, rasa, karsa, dan perilaku berbangsa dan bernegara Indonesia yang berdasarkan nilai-nilai Pancasila, norma UUD 1945, keberagaman dengan prinsip Bhinneka Tunggal Ika, dan komitmen terhadap NKRI. Atas dasar kedua konsep itu maka" Berdasarkan kedua konsep tersebut Pembangunan Karakter Bangsa dimaknai sebagai “... upaya kolektif-sistemik suatu negara kebangsaan untuk mewujudkan kehidupan berbangsa dan bernegara yang sesuai dengan dasar dan ideologi, konstitusi, haluan negara, serta potensi kolektifnya dalam konteks kehidupan nasional, regional, dan global yang berkeadaban untuk membentuk bangsa yang tangguh, kompetitif, berakhlak mulia, bermoral, bertoleran, bergotong royong, patriotik, dinamis, berbudaya, dan berorientasi Ipteks berdasarkan Pancasila dan dijiwai oleh iman dan takwa kepada Tuhan Yang Maha Esa." Untuk mengejawantahkan gagasan dan komitmen pembangunan karakter bangsa tersebut ditetapkan sejumlah strategi dasar yang mencakup “...proses sosialisasi, pendidikan dan pembelajaran, pemberdayaan, pembudayaan, dan kerja sama seluruh komponen bangsa dan negara".

\section{KESIMPULAN}

Pembangunan karakter bangsa dijadikan arus utama pembangunan nasional. Hal itu mengandung arti bahwa setiap upaya pembangunan harus selalu diarahkan untuk memberi dampak positif terhadap pengembangan karaker. Mengenai hal tersebut secara konstitusional sesungguhn ya sudah tecermin dari misi pembangunan nasional yang memosisikan pendidikan karakter sebagai misi pertama dari delapan misi guna mewujudkan visi pembangunan nasional, sebagaimana tercantum dalam Rencana Pembangunan Jangka Panjang Nasional Tahun 2005 - 2025, yaitu “...terwujudnya karakter bangsa yang tangguh, kompetitif, berakhlak mulia, dan bermoral berdasarkan Pancasila, yang dicirikan dengan watak dan prilaku manusia dan masyarakat Indonesia yang beragam, beriman dan bertakwa kepada Tuhan Yang Maha Esa, berbudi luhur, bertoleran, bergotongroyong, berjiwa patriotik, berkembang dinamis, dan berorientasi ipteks." Pembangunan karakter bangsa memiliki cakupan dan tingkat urgensi yang sangat luas dan bersifat multidimensional. Sehingga hal ini sangat penting bila diterapkan di lingkungan sekolah sebagai pencetak calon generasi penerus bangsa.

\section{REFERENSI}

Sukowati Praptining, 2008, Pendidikan Kewarganegaraan, UB Press

Udin S.Winataputra, 2010, Implementasi Kebijakan Nasional Pembangunan Karakter Bangsa, Melalui Pendidikan Karakter, PPs-UT dan Tim Pendidikan Karakter Diknas

Republik Indonesia (2010) Kebijakan Nasional Pembangunan Karakter Bangsa , Jakarta: Kemko Kesejahteran Rakyat.

Republik Indonesia (2010) Disain Induk Pendidikan Karakter, Jakarta: Kemdiknas.

Republik Indonesia (2010) Peraturan Pemerintah Republik Indonesia Nomor 17 Tahun 2010 Tentang Pengeloaan dan Penyelenggaraan Pendidikan, Jakarta: Kemdiknas 